\title{
Evaluation of effects of exposure conditions on the biological responses of Gammarus pulex exposed to cadmium
}

\author{
F. Duman - M. Kar
}

Received: 19 March 2013/Revised: 4 July 2013/Accepted: 3 November 2013/Published online: 3 December 2013

(C) Islamic Azad University (IAU) 2013

\begin{abstract}
This study was conducted to determine the single and combined effects of cadmium $(\mathrm{Cd})$ exposure at different concentrations and durations on biological responses in Gammarus pulex. The animals were exposed to $4,8,16$ or $32 \mu \mathrm{g} \mathrm{l}^{-1}$ of $\mathrm{CdCl}_{2}$ for $24,48,72$ or $96 \mathrm{~h}$, respectively. Cd accumulation, protein content, malondialdehyde content (MDA) and three antioxidant enzymes superoxide dismutase (SOD), catalase (CAT) and glutathione peroxidase (GPx) were studied. The results were analyzed with two-way analysis of variance (two-way ANOVA) to assess the significance of the effects of exposure concentration and duration and their combined effects. The highest accumulation of Cd was found as $15.07 \mu \mathrm{g} \mathrm{g}^{-1}$ at $32 \mu \mathrm{g} \mathrm{l}^{-1}$ and $96-\mathrm{h} \mathrm{Cd}$ exposure. There was a significant correlation between accumulated $\mathrm{Cd}$ concentration and MDA and protein content and GPx activity. Although there was no significant synergistic effect of duration and concentration on Cd accumulation, a significant synergy of duration and concentration was observed in all other studied parameters. Interestingly, with the exception of GPx activity, the effect of concentration was greater than the effect of duration for all studied parameters. GPx activity showed that duration had a greater effect than concentration. Additionally, both SOD and GPx are more effective than CAT during Cd stress. The results of this study may be useful for understanding the relationship between organisms and environmental toxins.
\end{abstract}

F. Duman $(\bowtie)$

Department of Biology, Faculty of Sciences, Erciyes University,

38039 Kayseri, Turkey

e-mail: fduman@erciyes.edu.tr

M. Kar

Graduate School of Natural and Applied Sciences,

Nevsehir University, 50300 Nevsehir, Turkey
Keywords Gammarus pulex Cadmium - Accumulation · Biological response

\section{Introduction}

Environmental pollution refers to pollution of the air, soil and water. The final destination of pollutants in air and soil is water, causing water pollution. As a result of the growth of technology, industrial and urban wastewaters, which contain sewage, have polluted lakes and rivers and threaten living organisms in the aquatic environment. In particular, agricultural wastewater, which contains high amounts of heavy metals and chemicals, mixes with freshwater sources, polluting water used for irrigation purposes. Consequently, aquatic organisms are exposed to high doses of heavy metals. Recently, scientists have focused on the accumulation of trace metals in the environment and their effects on living organisms (Rainbow and Moore 1990; Zeng et al. 2013). Aquatic organisms are a vital part of the food chain; therefore, these heavy metals are transferred to other steps of the food chain. This situation is very important consequence for public health. Moreover, toxic organic wastes can form complexes with metals or transform them into other compounds that are more toxicant; these forms may cause serious problems (Eisler 1988). Studies have demonstrated that $\mathrm{Cd}$ is very toxic, mutagenic and carcinogenic to plants, animals and humans (Seidman et al. 1986; Järup and Åkesson 2009). There are several sources of $\mathrm{Cd}$ pollution such as the smelting of various metals, the use of fossil fuels, municipal waste disposal and mining activities. In addition, pesticides and phosphate fertilizers contains $\mathrm{Cd}$ too much and so may result in increased $\mathrm{Cd}$ concentration (Felten et al. 2008). 
Aquatic organisms are more sensitive to metal pollution than terrestrial organisms, and toxic substances can accumulate in the bodies of aquatic organisms. Although, aquatic organisms have a low biomass, they represent different trophic levels, and they are widely exposed to heavy metals (Alves et al. 2009; Schaller et al. 2011). It has shown in prior studies that the production reactive oxygen species (ROS) was increased, accelerating oxidative stress. The biochemical end products that are generated, superoxide radical, hydroxyl radical and $\mathrm{H}_{2} \mathrm{O}_{2}$ which are all referred to as ROS, can damage proteins, membrane lipids and nucleic acids. MDA can serve as an indicator of oxidative damage (Anane and Creppy 2001). One response of living organisms which may be the most important in the case of oxidative stress is to increase the activity of antioxidant enzymes such as SOD, CAT and GPx. To prevent cell damage, superoxide radicals are converted to $\mathrm{H}_{2} \mathrm{O}_{2}$ by the action of SOD. Subsequently, $\mathrm{H}_{2} \mathrm{O}_{2}$ is broken down by CAT and GPx into harmless $\mathrm{H}_{2} \mathrm{O}$ and $\mathrm{O}_{2}$. Many studies have emphasized that $\mathrm{Cd}$ stress can change MDA content and antioxidant enzyme activity in insects.

Amphipoda is one of the most important organisms in aquatic food web and has been used in acute toxicity studies with various chemicals. Many studies have explored the impacts of heavy metals on this organism ( $\mathrm{Wu}$ and Chen 2005; Pestana et al. 2007; Fialkowski et al. 2009). Generally, earlier studies have focused on the effects of environmental pollution or an external source of heavy metals. Information about the biological response to $\mathrm{Cd}$ exposure at sub-lethal doses is limited. So far, there is a lack of information about duration-concentration interactions in aquatic animals exposed to $\mathrm{Cd}$. In this study, a freshwater gammarid (Gammarus pulex), because this species is very common, widely distributed, can tolerate a certain stress ratio, and it has been used in many ecotoxicology studies furthermore; this organism is a food source for organisms such as frogs, fish and birds. The aims of this study were (1) to determine the biological response of $G$. pulex exposed to various $\mathrm{Cd}$ concentrations and durations, (2) to determine the effects of exposure concentration and duration on various biological parameters, and (3) to reveal the single and combined effects of concentration and duration on $\mathrm{Cd}$ accumulation and biological response.

\section{Materials and methods}

Sampling and maintenance of the animals

Gammarus pulex samples were collected from Soysalli spring, Kayseri, Turkey, with a sieve in December, 2010. Prior to the experiment, glass containers were disinfected by immersing them in $1 \%(\mathrm{v} / \mathrm{v}) \mathrm{NaCl}$ for 3-5 min and then rinsed with distilled water three times (Duman et al. 2010). The organisms were quickly transported to the laboratory in plastic vessels, where they were kept at $12{ }^{\circ} \mathrm{C}$ in a container filled with spring water. The animals were then adapted to a photoperiod of $16 \mathrm{~h}$ of light and $8 \mathrm{~h}$ of darkness (Felten et al. 2008). The animals were fed alder leaves (Alnus glutinosa) supplemented with Tetramin ${ }^{\circledR}$ fish food. The most active and healthy individuals were selected for the experiments. All experimental studies were conducted in hydrobiology laboratories (Department of Biology, Erciyes University, Turkey) at 2011.

\section{$\mathrm{LC}_{50}$ assessment}

First, the experimental assembly was set up to determine the $\mathrm{LC}_{50} \mathrm{Cd}$ concentration and the upper concentration limit for subsequent experiments. Twenty individuals were placed in conical flasks filled with $400 \mathrm{ml}$ of spring water. The animals were exposed to different concentrations of $\mathrm{CdCl}_{2}\left(0,5,10,25,50,100\right.$, or $\left.250 \mu \mathrm{g} \mathrm{l}^{-1}\right)$ for $24,48,72$ or $96 \mathrm{~h}$. Dead and living individuals were counted, and the dead animals were removed from the conical flasks. All experiments were conducted in triplicate.

\section{Cd exposure experiments}

These experiments were conducted based on the 96-h $\mathrm{LC}_{50}$ concentration $\left(45 \mathrm{~g} \mathrm{l}^{-1}\right)$. G. pulex samples were exposed to $0,4,8,16$ or $32 \mu \mathrm{g} \mathrm{l}^{-1}$ of $\mathrm{CdCl}_{2}$ for $24,48,72$ or $96 \mathrm{~h}$, respectively. All flasks were well aerated. There were no dead individuals during the experiments. At the end of the experiments, samples were taken with plastic sieves and then washed with distilled water, dried and stored at $20{ }^{\circ} \mathrm{C}$ for later analysis.

\section{Quantification of Cd}

The samples were dried at $70{ }^{\circ} \mathrm{C}$. Dried samples $(0.3 \mathrm{~g})$ were digested with $10 \mathrm{ml}$ of pure $\% 37 \mathrm{HNO}_{3}$ using the CEM Mars 5 (CEM Corporation Mathews, NC, USA) microwave digestion system. The digestion conditions were as follows: maximum power was 1,200 W, power was $100 \%$, ramp was $20 \mathrm{~min}$, pressure was 180 psi, temperature was $200{ }^{\circ} \mathrm{C}$, and hold time was $10 \mathrm{~min}$. After digestion, the samples were centrifuged (4,000 rpm; $10 \mathrm{~min}$ ), and the volume of each sample was adjusted to $25 \mathrm{ml}$ using double-deionized water. Seronorm Trace Elements Whole Blood L-3 (Sero AS, Billingstad, Norway) was used as the standard material. The total $\mathrm{Cd}$ concentration was determined using Inductively Coupled PlasmaOptical Emission Spectroscopy (Varian-Liberty II, ICPOES). The stability of the device was evaluated after every run of ten samples by analyzing an internal standard. 
Reagent blanks were also prepared to detect any potential contamination during the digestion and analytic procedures. All samples were analyzed in triplicate. Chemicals used in this study were analytical reagent grade (Merck, Darmstadt, Germany).

\section{Lipid peroxidation (MDA)}

Gammarus samples were homogenized with $3 \mathrm{ml}$ of $0.5 \%$ TBA (thiobarbituric acid) in $20 \%$ TCA (trichloroacetic acid). The homogenate was incubated at $95{ }^{\circ} \mathrm{C}$ for $30 \mathrm{~min}$, and then ice was used to stop the reaction. The samples were centrifuged at $10,000 \times g$ for $10 \mathrm{~min}$, and the absorbance of the resulting supernatant was recorded at 532 and $600 \mathrm{~nm}$. The amount of (MDA) was calculated by subtracting the non-specific absorbance at $600 \mathrm{~nm}$ from the absorbance at $532 \mathrm{~nm}$ (Ohkawa et al. 1979).

Total protein content and antioxidant enzyme activity

Protein content was determined by the Bradford method using bovine serum albumin (BSA) as the standard protein (Bradford 1976). Gammarus samples (0.5 g) were homogenized at $4{ }^{\circ} \mathrm{C}$ in $1 \mathrm{ml}$ of a solution containing $0.1 \mathrm{M}$ Tris, $0.005 \mathrm{mM}$ EDTA, and $1 \%$ polyvinylpyrrolidone (PVP (w/ v)). The homogenate was centrifuged at $15,000 \times g$ at $4{ }^{\circ} \mathrm{C}$ for $20 \mathrm{~min}$. The supernatants were stored at $-20^{\circ} \mathrm{C}$ for subsequent SOD, CAT, and GPx activity measurements.

Superoxide dismutase activity was measured through the inhibition of nitroblue tetrazolium (NBT) reduction by $\mathrm{O}_{2}{ }^{-}$generated by the xanthine/xanthine oxidase system. Firstly, a reaction mixture was prepared. This mixture contained $20 \mathrm{mM} \mathrm{NaHPO}$ (pH 7.5), $0.1 \mathrm{mM}$ EDTA, $10 \mathrm{mM}$ methionine, $0.1 \mathrm{mM}$ NBT and $0.005 \mathrm{mM}$ riboflavin. An aliquot of protein $\left(50 \mu \mathrm{g} \mathrm{ml}^{-1}\right)$ was added to a tube and mixed with $3 \mathrm{ml}$ of the reaction mixture. One SOD activity unit was defined as the amount of enzyme causing $50 \%$ inhibition in a 1-ml reaction solution per $\mathrm{mg}$ of tissue protein. The result was expressed in units of protein $\mathrm{mg}^{-1}$ (Beauchamp and Fridovich 1971).

To measure CAT activity, an extraction has been performed with an extraction step with a buffer containing $50 \mathrm{mM}$ Tris $\mathrm{HCl}$ (pH 7.0), $0.1 \mathrm{mM}$ EDTA, $1 \mathrm{mM}$ phenylmethylsulfonyl fluoride (PMSF) and $1 \%$ PVP, according to the method of Aebi (1974). The reaction mixture consisted of $2.5 \mathrm{ml}$ of $50 \mathrm{mM}$ sodium phosphate buffer $(\mathrm{pH}$ 7.0), $300 \mu \mathrm{l}$ of $20 \mathrm{mM} \mathrm{H}_{2} \mathrm{O}_{2}$, and a suitable aliquot of enzyme. The change in absorbance was measured at $240 \mathrm{~nm}$ (extinction coefficient $0.04 \mathrm{~cm}^{2} \mu \mathrm{mol}^{-1}$ ). Enzyme activity was expressed in units of protein $\mathrm{mg}^{-1}$.

Glutathione peroxidase was assayed spectrophotometrically using glutathione (GSH) as a substrate. The decrease in the enzymatic reaction of GSH (excluding the effect of the non-enzymatic reaction) was measured as the absorption at $412 \mathrm{~nm}$. One unit of GPx activity was defined as a decrease of $1 \mathrm{nmol} \mathrm{l}^{-1}$ GSH (excluding the effect of the non-enzymatic reaction) in the enzymatic reaction of $1 \mathrm{mg}$ of protein per minute (Lijun et al. 2005).

Statistical analysis

The Kolmogorov-Smirnov test and Levene's test were used to ensure the normality assumption and the homogeneity of variances, respectively. Two-way analysis of variance was used to assess the significance of the effects of exposure concentration and duration and their interaction. Tukey's test was used in the post hoc analysis. The data were analyzed using the SPSS 15.0 software package, and $P$ values $<0.05$ were considered significant. Additionally, the association effects of each factor with the ANOVA model were analyzed by calculating their partial Eta-squared $\left(\eta^{2}\right)$ values. Pearson correlation test was used to determine the correlation between accumulated $\mathrm{Cd}$ and the studied parameters. Probit analysis was conducted using the same statistical program to estimate $\mathrm{LC}_{50}$ values of the $\mathrm{Cd}$ concentration.

\section{Results and discussion}

\section{LC 50 and Cd accumulation}

In this study, we determined that the $\mathrm{LC}_{50}$ concentrations for G. pulex exposure to $\mathrm{Cd}$ for $24,48,72$ and $96 \mathrm{~h}$ were 109.6, 74.36, 63.5 and $48.2 \mu \mathrm{g} 1^{-1}$, respectively. As expected, the highest accumulation of $\mathrm{Cd}\left(15.07 \mu \mathrm{g} \mathrm{g}^{-1}\right)$ was observed at $32 \mu \mathrm{g}^{-1}$ and 96-h Cd exposure (Fig. 1a). According to the two-way ANOVA analysis, both exposure and duration were significant for $\mathrm{Cd}$ accumulation $(P<0.001)$ (Table 1), but the combination of duration and exposure was not significant for $\mathrm{Cd}$ accumulation $(P>0.05)$. Exposure concentration explained $75 \%$ of the total variance in $\mathrm{Cd}$ accumulation in the exposed $G$. pulex (Table 1). Exposure duration accounted for $35 \%$ of the total variance, and the combined effect of the concentration and duration accounted for $15 \%$. According to the post hoc analysis test, at the end of the study, there were no differences in the 4, 8 and $16 \mu \mathrm{g}^{-1} \mathrm{Cd}$ exposures, but at $32 \mu \mathrm{g} 1^{-1} \mathrm{Cd}$, the accumulation was higher than all the other $\mathrm{Cd}$ concentrations $(P<0.05)$ (Table 2$)$.

\section{MDA levels}

Malondialdehyde content was calculated to determine the cell membrane damage caused by $\mathrm{Cd}$ accumulation. The highest MDA content was observed at $32 \mu \mathrm{g} \mathrm{l}^{-1}$ and 96-h $\mathrm{Cd}$ exposure as $6.3 \mu \mathrm{mol} \mathrm{g}^{-1}$ (Fig. 1b). Both duration and 
Fig. 1 The effects of concentration and duration on Cd accumulation (a), MDA (b), protein (c), SOD (d), CAT (e), and GPx (f) in G. pulex. The reported values are the means of three replicates, and the vertical bars indicate standard error
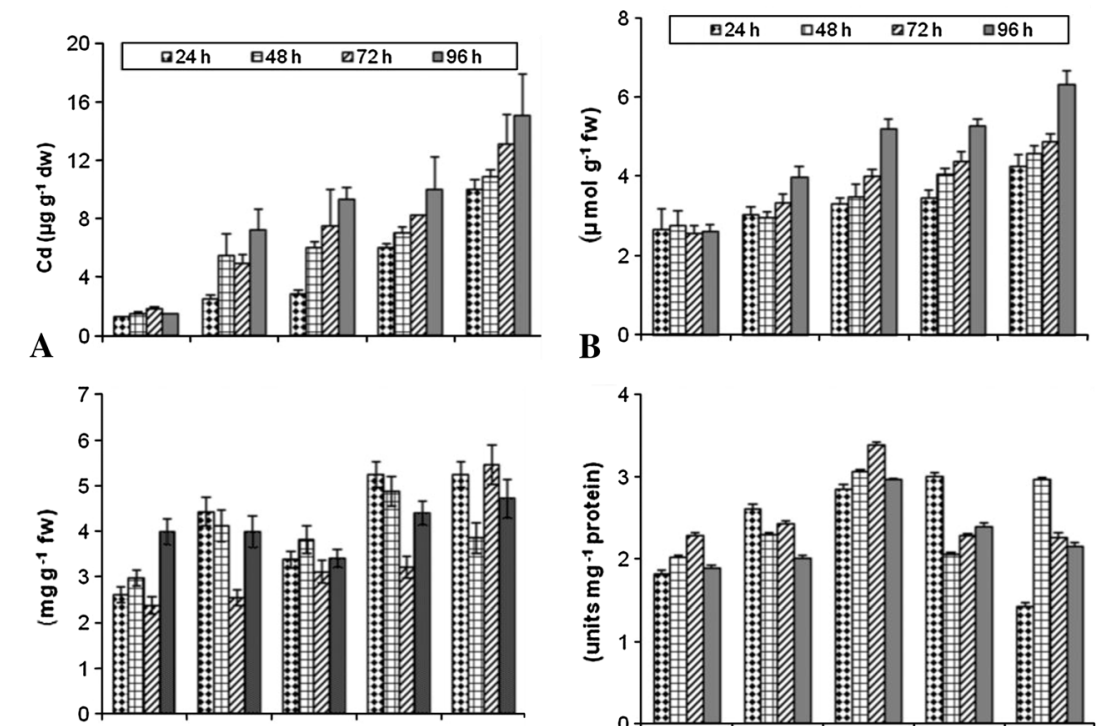

C
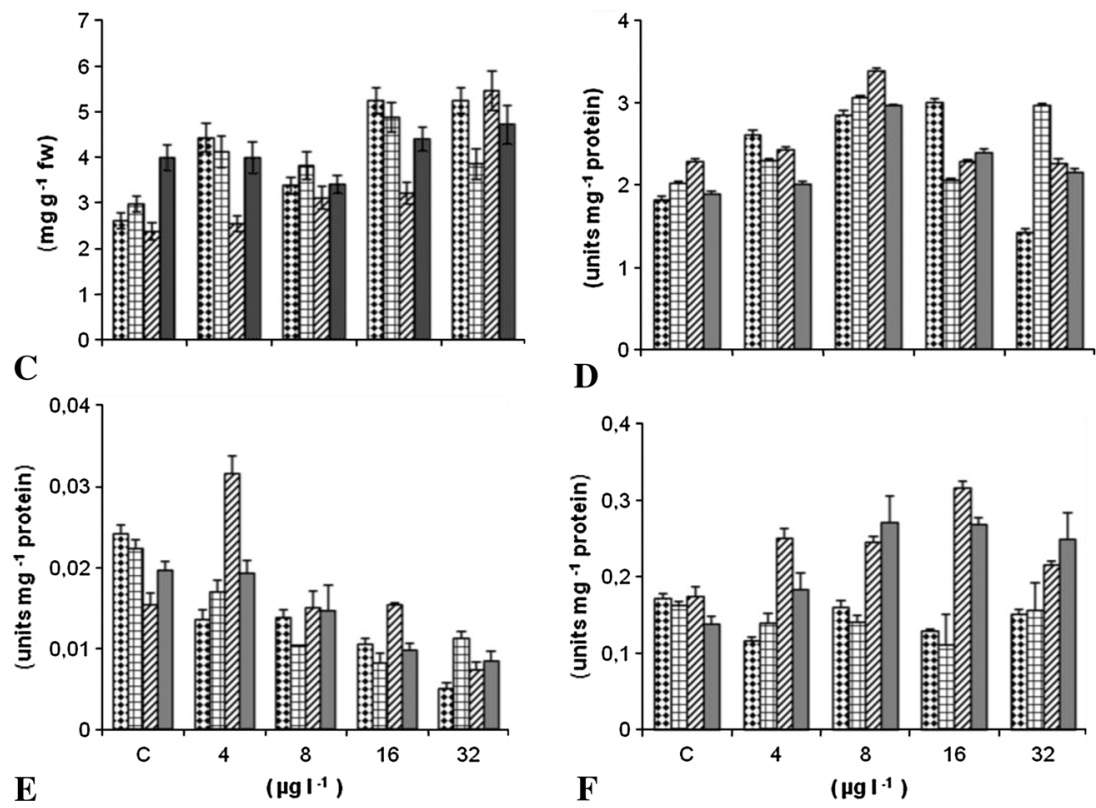



D concentration significantly affected MDA content. Furthermore, the combined effect of duration and concentration was also significant $(P<0.05)$. The duration of exposure affected $65 \%$ of the total variance, concentration affected $82 \%$, and the combined effect of the concentration and duration was $41 \%$ (Table 1). In the post hoc analysis test, the 96-h application MDA content was higher than that of the 24 and $48 \mathrm{~h}$ (Table 2). In addition, lower MDA activity occurred at $4 \mu \mathrm{g} 1^{-1}$ and the highest MDA activity occurred at $32 \mu \mathrm{g}^{-1}$. There is no significance between $8 \mu \mathrm{g} \mathrm{l}^{-1}$ and $16 \mu \mathrm{g} \mathrm{l}^{-1}(P>0.05)$. There was a significant positive correlation $(R=0.877, \quad P<0.01)$ between MDA content and accumulated Cd (Table 3).

\section{Protein content}

The effect of Cd duration and exposure concentration on protein content is shown in Fig. 1c. The highest protein content was observed with the $72 \mathrm{~h} 32 \mu \mathrm{g} \mathrm{l} \mathrm{l}^{-1}$ exposure $\left(5.46 \mathrm{mg} \mathrm{g}^{-1}\right.$ ). According to the two-way ANOVA test, both duration and concentration affected protein content $(P<0.001)$. Furthermore, the combined effect was also significant $(P<0.001)$. Additionally, the results of the two-way analysis of variance test determined that the effect of concentration contributed $79 \%$ of the variance, the effect of duration contributed $38 \%$ and the combined effect of concentration and duration contributed $64 \%$ (Table 1). According to the post hoc analysis for protein content, there were no significance differences among the 24-,48- and 96-h exposures, but the 72-h exposure showed lower protein content than the others $(P<0.05)$. The protein content with the $8 \mu \mathrm{g}^{-1}$ exposure was lower than with the other exposures (Table 2). The highest protein content was found with the $32 \mu \mathrm{g} 1^{-1}$ exposure $(P<0.05)$. A significant positive correlation $(R=0.661, P<0.01)$ was determined between the protein content and the accumulated Cd (Table 3).

\section{Antioxidative enzymes}

The concentration- and duration-dependent effects of $\mathrm{Cd}$ exposure on antioxidant enzyme activity in G. pulex are shown in Fig. 1d-f. The highest enzyme activities were observed for SOD with the $72 \mathrm{~h}, 8 \mu \mathrm{g} \mathrm{l}^{-1}$ exposure (3.33 Units $\mathrm{mg}^{-1}$ ), for CAT in the $72 \mathrm{~h}, 4 \mu \mathrm{g} \mathrm{l}^{-1}$ exposure

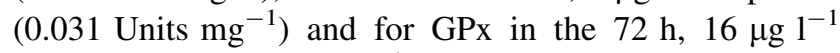

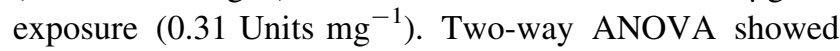
that both $\mathrm{Cd}$ exposure concentration and duration effects 
were significant for the SOD, CAT and GPx activities (Table 1).

The effects of $\mathrm{Cd}$ exposure concentration and duration significantly altered SOD activity $(P<0.001)$. Moreover,

Table 1 Summary of two-way analyses of variance for the studied parameters

\begin{tabular}{|c|c|c|c|c|}
\hline & $d f$ & $F$ & $P$ & Effect size $^{\mathrm{a}}$ \\
\hline \multicolumn{5}{|l|}{ Accumulation } \\
\hline Duration & 3 & 7.204 & 0.001 & 0.35 \\
\hline Concentration & 4 & 30.48 & $<0.001$ & 0.753 \\
\hline $\begin{array}{l}\text { Duration } \times \text { Concentration } \\
M D A\end{array}$ & 12 & 0.593 & 0.835 & 0.151 \\
\hline Duration & 3 & 24.43 & $<0.001$ & 0.647 \\
\hline Concentration & 4 & 47.04 & $<0.001$ & 0.825 \\
\hline $\begin{array}{l}\text { Duration } \times \text { Concentration } \\
\text { Protein }\end{array}$ & 12 & 2.34 & $<0.05$ & 0.413 \\
\hline Duration & 3 & 8.89 & $<0.001$ & 0.381 \\
\hline Concentration & 4 & 27.12 & $<0.001$ & 0.778 \\
\hline $\begin{array}{l}\text { Duration } \times \text { Concentration } \\
S O D\end{array}$ & 12 & 5.745 & $<0.001$ & 0.64 \\
\hline Duration & 3 & 60.39 & $<0.001$ & 0.819 \\
\hline Concentration & 4 & 586.68 & $<0.001$ & 0.983 \\
\hline $\begin{array}{l}\text { Duration } \times \text { Concentration } \\
C A T\end{array}$ & 12 & 149.49 & $<0.001$ & 0.978 \\
\hline Duration & 3 & 37.32 & $<0.05$ & 0.218 \\
\hline Concentration & 4 & 3.71 & $<0.001$ & 0.789 \\
\hline $\begin{array}{l}\text { Duration } \times \text { Concentration } \\
G P x\end{array}$ & 12 & 6.30 & $<0.001$ & 0.654 \\
\hline Duration & 3 & 3.08 & $<0.001$ & 0.658 \\
\hline Concentration & 4 & 25.62 & $<0.05$ & 0.236 \\
\hline Duration $\times$ Concentration & 12 & 3.64 & $<0.001$ & 0.522 \\
\hline
\end{tabular}

Values $P<0.05$ are given in bold; $d f$ degrees of freedom

${ }^{a}$ Effect size is given in partial eta-squared $(\eta 2)$ the contribution of exposure duration to the variance of SOD activity was $82 \%$, that of exposure concentration was $98 \%$ and their combined effect contributed $98 \%$. In the post hoc analysis, the SOD activity of the 96-h exposure was lower than the other exposures $(P<0.05)$ (Table 2$)$. All concentration exposures showed different SOD activities. The highest activity was observed with the $8 \mu \mathrm{g}{ }^{-1}$ exposure and the lowest activity was with the $32 \mu \mathrm{g}^{-1}$ exposure.

$\mathrm{Cd}$ exposure concentration, duration and their combined effects all significantly altered CAT activity $(P<0.001)$. The contribution of exposure duration to the variance of CAT activity was $22 \%$, that of exposure concentration was $79 \%$ and their combined effect contributed $65 \%$ (Table 1). The post hoc analysis revealed that CAT activity was higher with the 72-h exposure than with the other exposures $(P<0.05)$. The lowest activity was observed with the $32 \mu \mathrm{g}^{-1}$ exposure, and the highest activity was with the $4 \mu \mathrm{g} \mathrm{l}^{-1}$ exposure. There was no correlation between CAT activity and accumulated Cd (Table 3).

The contribution of exposure duration to the variance of GPx activity was $66 \%$, that of exposure concentration was $24 \%$, and their combined effect contributed $52 \%$. The post hoc analysis showed that the 72-h exposure yielded higher GPx activity than the other exposures $(P<0.05)$. There was no difference between the 24- and 48-h exposures, but the 72- and 96-h exposure showed a higher GPx activity than the others. There were no statistically significant differences among any of the exposure concentrations (Table 2). A significant positive correlation $(R=0.481$, $P<0.01)$ was determined between GPx activity and accumulated $\mathrm{Cd}$ (Table 3).

The 48-h $\mathrm{Cd}$ exposure $\mathrm{LC}_{50}$ value was lower than that reported in other studies $\left(400 \mu \mathrm{g} \mathrm{Cd}^{-1}\right.$ (Williams et al. 1985) and $680 \mu \mathrm{g} \mathrm{Cd}^{-1}$ (Wright 1980). These differences may occur because $\mathrm{Cd}$ can harm the gills of G. pulex; there were differences between the studied populations or the

Table 2 Mean values of $\mathrm{Cd}$ accumulation, MDA and protein content, and antioxidant enzyme activities of G. pulex exposed to Cd in a durationand concentration-dependent manner $(C$ Control)

\begin{tabular}{|c|c|c|c|c|c|c|c|}
\hline & & $\begin{array}{l}\text { Accumulation } \\
\left(\mu \mathrm{g} \mathrm{g}^{-1} \mathrm{dw}\right)\end{array}$ & $\begin{array}{l}\text { MDA } \\
\left(\mu \mathrm{mol} \mathrm{g}{ }^{-1} \mathrm{fw}\right)\end{array}$ & $\begin{array}{l}\text { Protein } \\
\left(\mathrm{mg} g-{ }^{1} \mathrm{fw}\right)\end{array}$ & $\begin{array}{l}\text { SOD (Units } \mathrm{mg}^{-1} \\
\text { protein) }\end{array}$ & $\begin{array}{l}\text { CAT (Units } \mathrm{mg}^{-1} \\
\text { protein) }\end{array}$ & $\begin{array}{l}\text { GPx (Units } \mathrm{mg}^{-1} \\
\text { protein) }\end{array}$ \\
\hline \multirow[t]{4}{*}{ Duration (h; $n=15$ ) } & 24 & $4.54 \pm 3.3^{\mathrm{a}}$ & $3.33 \pm 0.7^{\mathrm{a}}$ & $1 \pm 0.25^{\mathrm{b}}$ & $2.34 \pm 0.6^{\mathrm{b}}$ & $0.013 \pm 0.006^{\mathrm{a}}$ & $0.15 \pm 0.02^{\mathrm{a}}$ \\
\hline & 48 & $6.19 \pm 3.3^{\mathrm{ab}}$ & $3.55 \pm 0.8^{\mathrm{ab}}$ & $0.98 \pm 0.1^{\mathrm{b}}$ & $2.48 \pm 0.5^{\mathrm{c}}$ & $0.014 \pm 0.005^{\mathrm{ab}}$ & $0.14 \pm 0.05^{\mathrm{a}}$ \\
\hline & 72 & $7.13 \pm 4.9^{\mathrm{bc}}$ & $3.81 \pm 0.9^{\mathrm{b}}$ & $0.83 \pm 0.29^{\mathrm{a}}$ & $2.5 \pm 0.4^{\mathrm{c}}$ & $0.016 \pm 0.008^{\mathrm{b}}$ & $0.24 \pm 0.05^{\mathrm{b}}$ \\
\hline & 96 & $8.6 \pm 5.25^{\mathrm{c}}$ & $4.66 \pm 1.37^{\mathrm{c}}$ & $0.98 \pm 0.17^{\mathrm{b}}$ & $2.3 \pm 0.4^{\mathrm{a}}$ & $0.014 \pm 0.006^{\mathrm{ab}}$ & $0.22 \pm 0.07^{\mathrm{b}}$ \\
\hline \multirow{5}{*}{$\begin{array}{l}\text { Concentration } \\
\quad\left(\mu \mathrm{g} 1^{-1} ; n=12\right)\end{array}$} & $\mathrm{C}$ & $1.5 \pm 0.3^{\mathrm{a}}$ & $2.63 \pm 0.5^{\mathrm{a}}$ & $0.7 \pm 0.1^{\mathrm{a}}$ & $2 \pm 0.2^{\mathrm{a}}$ & $0.02 \pm 0.004^{\mathrm{c}}$ & $0.16 \pm 0.02^{\mathrm{a}}$ \\
\hline & 4 & $5 \pm 2.4^{\mathrm{b}}$ & $3.32 \pm 0.5^{\mathrm{b}}$ & $0.94 \pm 0.2^{\mathrm{bc}}$ & $2.34 \pm 0.2^{c}$ & $0.02 \pm 0.007^{\mathrm{c}}$ & $0.17 \pm 0.06^{\mathrm{a}}$ \\
\hline & 8 & $6.4 \pm 3.6^{\mathrm{b}}$ & $3.98 \pm 0.85^{\mathrm{c}}$ & $0.86 \pm 0.1^{\mathrm{b}}$ & $3 \pm 0.2^{\mathrm{e}}$ & $0.01 \pm 0.005^{\mathrm{b}}$ & $0.2 \pm 0.07^{\mathrm{a}}$ \\
\hline & 16 & $7.8 \pm 2.3^{\mathrm{b}}$ & $4.28 \pm 0.74^{\mathrm{c}}$ & $1.05 \pm 0.18^{\mathrm{c}}$ & $2.43 \pm 0.4^{\mathrm{d}}$ & $0.01 \pm 0.003^{\mathrm{ab}}$ & $0.2 \pm 0.09^{\mathrm{a}}$ \\
\hline & 32 & $12.3 \pm 3.7^{\mathrm{c}}$ & $4.99 \pm 0.9^{\mathrm{d}}$ & $1.2 \pm 0.24^{\mathrm{d}}$ & $2.2 \pm 0.6^{\mathrm{b}}$ & $0.008 \pm 0.002^{\mathrm{a}}$ & $0.19 \pm 0.06^{\mathrm{a}}$ \\
\hline
\end{tabular}

Values represent mean $\pm \mathrm{SD}$

Different superscripts in each group denote significant difference between means according Tukey’s test $(P<0.05)$ 
organism status (e.g., life cycle stage, molting cycle stage, or productive period), or there were differences in the experimental conditions inducing changes in cadmium speciation and bioavailability acclimation (Felten et al. 2008). Maltby 1995 compared the durability of two aquatic creatures (G. pulex and Asellus aquaticus) under low oxygen conditions and reported that $A$. aquaticus adapted 5 times as well as G. pulex. Additionally, the differences between earlier studies and ours may be due to differing environmental conditions.

Studies have been conducted on the accumulation of heavy metals in plants and animals, showing the adverse effects of heavy metals. It remains to be determined whether aquatic organisms can accumulate essential heavy metals in their bodies (Calhôa et al. 2006). All aquatic organisms accumulate nutrients directly from their environment and from their food and this accumulation is related to metal bioactivity (Rainbow and Wen-Xiong 2001). It has been observed that increased $\mathrm{Cd}$ accumulation in G. pulex depends on the duration and the concentration of Cd exposure. In a similar study, Craig et al. (1998) exposed midge-fly nymphs to (10 $\mathrm{nM}$ for 5 and 140 days) Cd. After 5 days, Cd residue was not detected in the fly body; however, after 140 days, Cd was found in all tissues of the samples. In another study conducted by Ungherese et al. (2010), it was determined that there were significant effects from both the concentration and the duration of exposure on metal accumulation by Talitrus saltator. Our findings support the studies mentioned above. In addition, we showed that the exposure concentration is statistically more important than the duration of exposure with respect to Cd accumulation in G. pulex.

There is a significant correlation between the accumulated $\mathrm{Cd}$ concentrations in all living organisms and their environmental $\mathrm{Cd}$ concentrations. Our findings are in accordance with earlier findings (Ugolini et al. 2004). Additionally, similar to our findings, Felten et al. (2008) determined that $\mathrm{Cd}$ accumulation increased when G. pulex was exposed to increased $\mathrm{Cd}$ concentrations. In this study, the highest $\mathrm{Cd}$ accumulation was found in the 96-h exposure. Similarly, in a study conducted using white shrimp (Litopenaeus vannamei) to determine metal accumulation, it was shown that the duration of $\mathrm{Cd}$ exposure was very important for $\mathrm{Cd}$ accumulation and that accumulation increased in proportion to exposure duration ( $\mathrm{Wu}$ and Chen 2005). A study by (Rainbow 2002) found that when a metal concentration was increased, metal accumulation also increased. It has been found that the highest accumulation of $\mathrm{Cd}$ in $G$. pulex occurred with the highest exposure concentration.

Lipid peroxidation is the main indicator of oxidative damage (Anane and Creppy 2001). In a study conducted by (Lei et al. 2011), freshwater crabs (Sinopotamon yangtsekiense) were exposed to different concentrations of $\mathrm{Cd}$
Table 3 Correlations between accumulated $\mathrm{Cd}$ and the studied parameters

\begin{tabular}{lllllll}
\hline & $\mathrm{Cd}$ & Protein & MDA & SOD & CAT & GPx \\
\hline Cd & 1 & & & & & \\
Protein & $0.661(* *)$ & 1 & & & & \\
MDA & $0.877(* *)$ & $0.582(* *)$ & 1 & & & \\
SOD & -0.020 & -0.126 & -0.103 & 1 & & \\
CAT & 0.002 & -0.158 & 0.050 & -0.085 & 1 & \\
GPx & $0.481(* *)$ & $0.388(* *)$ & $0.443(* *)$ & 0.123 & 0.095 & 1 \\
\hline
\end{tabular}

** Correlation is significant at the 0.01 level

for 1, 3, 5 or 7 days. Acute intoxication of Cd after 5 and 7 days of exposure caused a statistically significant increase in MDA concentrations compared with the control. High MDA levels indicated that the crab defense system was overwhelmed, which was especially evident at the end of the 7-day exposure, when the activities of CAT and GPx were low and the SOD activity was high. However, Cd had no effect on lipid peroxidation during shortterm exposure ( 1 and 3 days). Our findings support the results of Lei et al. (2011). Although CAT activity showed a tendency to decrease for $96 \mathrm{~h}$, MDA levels increased continuously. Wu and Chen (2005) determined that MDA content increased in response to $\mathrm{Cd}$ exposure depending on the duration and concentration furthermore; they reported a linear correlation between MDA and Cd exposure. Similarly, our result showed that MDA content increased with both exposure concentration and duration. Additionally, the exposure concentration has a greater effect than the exposure duration. Furthermore, we also determined that there was a synergistic effect between the concentration and the duration on MDA content.

Protein content changes in living organisms are the one of the main signs of an applied stress. A field study was conducted using Carcinus maenas (shore crab) to assess the potential use of metallothionein (MT) and stress proteins (stress-70) as biomarkers of trace metal exposure and indicators of stress factors. At the end of study, the concentrations of MT and stress proteins were higher in polluted areas than in non-polluted sampling areas. This finding is discussed with regard to its interpretation, and it was concluded that stress protein contents can be used as potential response biomarkers, constituting tools for use in ecological impact assessments (Pedersen et al. 1997). Another study reported a positive correlation between stress protein (MT) and accumulated Cd (Ungherese et al. 2010). A study was conducted examining the relationship between time-dependent $\mathrm{Zn}$ and $\mathrm{Cd}$ accumulations and metallothionein-like protein (MTLP) induction in the digestive glands of mussels (Perna viridis) which were measured under different exposure conditions. The MTLP 
level increased continuously when mussels were exposed to low or medium levels of $\mathrm{Zn}$ and $\mathrm{Cd}$ in the media, reaching their maximum levels on day 4 and then decreased when they were exposed to solutions with high levels of $\mathrm{Zn}$ and $\mathrm{Cd}$. These results suggested that both MTLP induction and metal precipitation are detoxification processes (Long et al. 2010). A similar study involving Potamonautes warreni found that MTLP bound Cd more effectively than $\mathrm{Cu}$ and $\mathrm{Zn}$. The biochemical responses of amphipod species were examined by exposing them to $\mathrm{CdCl}_{2}$ and examining various biochemical parameters (Timofeyev et al. 2008). The results showed that antioxidant enzyme activity and stress protein (HsPs) contents increased depending on the Cd concentration. In this study, total protein content in $G$. pulex tended to increase depending on the $\mathrm{Cd}$ exposure concentration and exposure duration. Moreover, Cd concentration had a statistically greater effect than exposure duration on total protein content.

It can be implied that some antioxidant enzymes, e.g., SOD, CAT and GPx, play important roles in clearing peroxidation products (Lei et al. 2011). Many studies have been conducted on stress-induced $\mathrm{Cd}$ effects and the antioxidant defense mechanisms of living organisms (Migula et al. 2004. In this study, Cd exposure induced some changes in G. pulex antioxidative stress enzymes.

Superoxide dismutase is an enzyme that converts the reactive and toxic superoxide radicals into hydrogen peroxide $\left(\mathrm{H}_{2} \mathrm{O}_{2}\right)$. Biochemical changes in $\mathrm{S}$. yangtsekiense after acute $\mathrm{Cd}$ exposure were studied, and it was found that exposure duration had a significant effect on SOD activity, with a positive correlation between increasing SOD activity and exposure duration (Lei et al. 2011). Similarly, it has been found that exposure duration significantly affected SOD activity, but did not show a tendency to increase. The highest SOD activity was found with the $8 \mu \mathrm{g} \mathrm{l}^{-1}$ exposure, and other SOD activity values for each exposure concentration were higher than the control group. (Hansen et al. 2008) reported that in the early stage of a metal experiment (at low concentration), there was a radical increase in antioxidant activity, and then antioxidant activity subsequently returned to its initial levels. The findings of Hansen's study support our results. In another work, the antioxidative defense enzymes of Pterostichus oblongopunctatus collected from a spatially polluted area were studied, and it was found that the SOD activity of samples taken from less polluted areas were higher than those in samples collected from polluted areas (Migula et al. 2004). Our results support these findings. The SOD activity with the $32 \mu \mathrm{g}^{-1}$ exposure was much lower than the SOD activity with the $8 \mu \mathrm{g} \mathrm{l}^{-1} \mathrm{Cd}$ exposure.
As a result of CAT and GPx activity, $\mathrm{H}_{2} \mathrm{O}_{2}$ is broken down to form water and oxygen which are harmless to cells. In earlier studies, it was shown that ROS species can inhibit CAT activity (Kono and Fridovich 1982; Escobar et al. 1996). S. yangtsekiense was exposed to Cd for 7 days. The amount of CAT increased up to 5 days of exposure, after which, a decrease was observed (Lei et al. 2011). Similarly, in our study, the activity of CAT increased for $48 \mathrm{~h}$, after which a decrease was observed compared with the control group. In the current study, both GPx and CAT have the same function, so the increase that occurred in the GPx activity may have been caused by a decrease in the observed CAT activity. Although there was a positive correlation between GPx and Cd accumulation, there was no correlation between CAT activity and $\mathrm{Cd}$ accumulation. In a similar study, CAT activity increased along with $\mathrm{Cd}$ exposure, and this increase suppressed the GPx increase (Zhang et al. 2011). Similarly, in our study, the increase in GPx activity may have been caused by a decrease in CAT activity.

A study conducted on Chinese grasshoppers (Oxya chinensis) that were exposed to $\mathrm{Cd}$ and assessed for antioxidant stress activity found that in the earlier stages of exposure, CAT activity was much higher than GPx activity, and the authors claimed that CAT is the first enzyme to respond to oxidative stress (Lijun et al. 2005). In contrast, it was found that GPx enzyme activity was generally higher than CAT activity. According to this result, we conclude that GPx induction is the first enzymatic response to Cd-induced oxidative stress in G. pulex. Antioxidative stress activity can change depending on sexuality, physiological phase, and species (Felten et al. 2008; Lei et al. 2011; Zhang et al. 2011). However, it was found that $\mathrm{Cd}$ exposure concentration and exposure duration can also alter antioxidative stress activity.

\section{Conclusion}

The sub-lethal $\mathrm{Cd}$ exposure concentrations were showed that sub-lethal $\mathrm{Cd}$ exposure concentrations and durations significantly affect the levels of antioxidative defense enzymes (SOD, CAT and GPx), MDA and protein content in G. pulex. Cd accumulation and MDA content increased depending on the exposure concentration and duration. These results imply that sublethal $\mathrm{Cd}$ exposure can cause oxidative stress. SOD and GPx are more effective than CAT during stress. Exposure concentration and duration have strong synergistic effects on antioxidant enzyme activity, MDA, and protein content. In contrast, it was observed no significant synergistic effect of exposure concentration and duration on $\mathrm{Cd}$ accumulation. The findings of the present study can be used in subsequent lethal-dose exposure studies and biomagnification studies. 
Acknowledgments This study was supported by Erciyes University Scientific Research Project Fund (No. FBA 07-32). The authors would like to thank Ahmet Ceylan for his technical support.

\section{References}

Aebi H (1974) Catalase. In: Bergmeyer HU (ed) Methods of enzymatic analysis. Verlag Chemie, Weinheim, pp 673-684

Alves LC, Borgmann U, Dixon DG (2009) Kinetics of uranium uptake in soft water and the effect of body size, bioaccumulation and toxicity to Hyalella azteca. Environ Pollut 157:2239-2247

Anane R, Creppy EE (2001) Lipid peroxidation as pathway of aluminium cytotoxicity in human skin fibroblast cultures: prevention by superoxide dismutase plus catalase and vitamins E and C. Hum Exp Toxicol 20:477-481

Beauchamp C, Fridovich I (1971) Superoxide dismutase: improved assays and an assay applicable to acrylamide gels. Anal Biochem 44:276-287

Bradford MM (1976) A rapid and sensitive method for the quantitation of microgram quantities of protein utilizing the principle of protein-dye binding. Anal Biochem 72:248-254

Calhôa CF, Soares AMVM, Mann RM (2006) Cadmium assimilation in the terrestrial isopod, Porcellio dilatatus: is trophic transfer important? Sci Total Environ 371:206-213

Craig A, Hare L, Charest PM, Tessier A (1998) Effect of exposure regime on the internal distribution of cadmium in Chironomus staegeri larvae (Insecta, Diptera). Aquat Toxicol 41:265-275

Duman F, Ozturk F, Aydin Z (2010) Biological responses of duckweed (Lemna minor L.) exposed to the inorganic arsenic species $\mathrm{As}(\mathrm{III})$ and $\mathrm{As}(\mathrm{V})$ : effects of concentration and duration of exposure. Ecotoxicology 19:983-993

Eisler R (1988) Zinc hazards to fish, wildlife, and invertebrates: a synoptic review: U.S. Dept. of the Interior, Fish and Wildlife Service. Biol Rep 85(12):92

Escobar JA, Rubio MA, Lissi EA (1996) SOD and catalase inactivation by singlet oxygen and peroxyl radicals. Free Radical Bio Med 20:285-290

Felten V, Charmantier G, Mons R, Geffard A, Rousselle P, Coquery M, Garric J, Geffard O (2008) Physiological and behavioural responses of Gammarus pulex (Crustacea : Amphipoda) exposed to cadmium. Aquat Toxicol 86:413-425

Fialkowski W, Calosi P, Dahlke S, Dietrich A, Moore PG, Olenin S, Persson LE, Smith BD, Špegys M, Rainbow PS (2009) The sandhopper Talitrus saltator (Crustacea: Amphipoda) as a biomonitor of trace metal bioavailabilities in European coastal waters. Mar Pollut Bull 58:39-44

Hansen BH, Altin D, Vang SH, Nordtug T, Olsen AJ (2008) Effects of naphthalene on gene transcription in Calanus finmarchicus (Crustacea : Copepoda). Aquat Toxicol 86:157-165

Järup L, Ảkesson A (2009) Current status of cadmium as an environmental health problem. Toxicol Appl Pharm 238:201-208

Kono Y, Fridovich I (1982) Inhibition of catalase by superoxide radicals. Fed Proc 41:1207

Lei W, Wang L, Liu D, Xu T, Luo J (2011) Histopathological and biochemical alternations of the heart induced by acute cadmium exposure in the freshwater crab Sinopotamon yangtsekiense. Chemosphere 84:689-694

Lijun L, Xuemei L, Yaping G, Enbo M (2005) Activity of the enzymes of the antioxidative system in cadmium-treated Oxya chinensis (Orthoptera Acridoidae). Environ Toxicol Phar 20:412-416

Long AM, Li CD, Chen SY, Yan W, Dang AC, Cheng YY, Lu DW (2010) Short-term metal accumulation and MTLP induction in the digestive glands of Perna virdis exposed to $\mathrm{Zn}$ and $\mathrm{Cd}$. J J Environ Sci-China 22:975-981

Maltby L (1995) Sensitivity of the crustaceans Gammarus pulex (L.) and Asellus aquaticus (L.) to short-term exposure to hypoxia and unionized ammonia: observations and possible mechanisms. Water Res 29:781-787

Migula P, Laszczyca P, Augustyniak M, Wilczek G, Rozpedek K, Kafel A, Woloszyn M (2004) Antioxidative defence enzymes, in beetles, from a metal pollution, gradient. Biologia 59:645-654

Ohkawa H, Ohishi N, Yagi K (1979) Assay for lipid peroxides in animal tissues by thiobarbituric acid reaction. Anal Biochem 95:351-358

Pedersen SN, Lundebye AK, Depledge MH (1997) Field application of metallothionein and stress protein biomarkers in the shore crab (Carcinus maenas) exposed to trace metals. Aquat Toxicol 37:183-200

Pestana JLT, Ré A, Nogueira AJA, Soares AMVM (2007) Effects of Cadmium and Zinc on the feeding behaviour of two freshwater crustaceans: Atyaephyra desmaresti (Decapoda) and Echinogammarus meridionalis (Amphipoda). Chemosphere 68:1556-1562

Rainbow PS (2002) Trace metal concentrations in aquatic invertebrates: why and so what? Environ Pollut 120:497-507

Rainbow P, Moore P (1990) Seasonal variation in copper and zinc concentrations in three talitrid amphipods (Crustacea). Hydrobiologia 196:65-72

Rainbow PS, Wen-Xiong W (2001) Comparative assimilation of Cd, $\mathrm{Cr}$, Se, and $\mathrm{Zn}$ by the barnacle Elminius modestus from phytoplankton and zooplankton diets. Mar Ecol Prog Ser (Halstenbek) 218:239-248

Schaller J, Brackhage C, Dudel EG (2011) Invertebrates minimize accumulation of metals and metalloids in contaminated environments. Water Air Soil Poll 218:227-233

Seidman LA, Bergtrom G, Gingrich DJ, Remsen CC (1986) Accumulation of cadmium by the fourth instar larva of the fly Chironomus thummi. Tissue Cell 18:395-405

Timofeyev MA, Shatilina ZM, Bedulina DS, Protopopova MV, Pavlichenko VV, Grabelnych OI, Kolesnichenko AV (2008) Evaluation of biochemical responses in Palearctic and Lake Baikal endemic amphipod species exposed to $\mathrm{CdCl}_{2}$. Ecotox Environ Safe 70:99-105

Ugolini A, Borghini F, Calosi P, Bazzicalupo M, Chelazzi G, Focardi S (2004) Mediterranean Talitrus saltator (Crustacea, Amphipoda) as a biomonitor of heavy metals contamination. Mar Pollut Bull 48:526-532

Ungherese G, Mengoni A, Somigli S, Baroni D, Focardi S, Ugolini A (2010) Relationship between heavy metals pollution and genetic diversity in Mediterranean populations of the sandhopper Talitrus saltator (Montagu) (Crustacea, Amphipoda). Environ Pollut 158:1638-1643

Williams KA, Green DWJ, Pascoe D (1985) Studies on the acute toxicity of pollutants to freshwater macroinvertebrates. I: cadmium. Arch Hydrobiol 102:461-471

Wright DA (1980) Cadmium and calcium interactions in the freshwater amphipod Gammarus pulex. Freshwater Biol 10:123-133

Wu JP, Chen HC (2005) Metallothionein induction and heavy metal accumulation in white shrimp Litopenaeus vannamei exposed to cadmium and zinc. Comp Biochem Phys C 140:383-394

Zeng J, Yang LY, Chuai XM, Chen XF, Zhao HY, Wu QL (2013) Comparison of metal(loid) concentrations in water, sediments and fish from two large shallow lakes. Int J Environ Sci Tech 10(6): 1209-1218

Zhang YP, Sun G, Yang ML, Wu HH, Zhang JZ, Song SJ, Ma EB, Guo YP (2011) Chronic accumulation of cadmium and its effects on antioxidant enzymes and malondialdehyde in Oxya chinensis (Orthoptera: Acridoidea). Ecotox Environ Safe 74:1355-1362 